\title{
Optimizing the separation characteristics of the waterinjection hydrocyclone using mathematical modelling
}

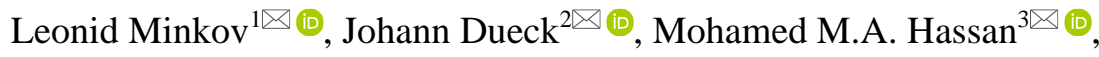 \\ Mahrous A.M. Ali $^{3 * \otimes(\odot)}$, Mohamed G. Farghaly ${ }^{3 \otimes}$ (1) \\ ${ }^{1}$ Tomsk State University, Tomsk, 634050, Russian Federation \\ ${ }^{2}$ Erlangen-Nuremberg University, Erlangen, 91054, Germany \\ ${ }^{3}$ Al-Azhar University, Qena, 83513, Egypt \\ *Corresponding author: e-mail mahrousali@azhar.edu.eg, tel. +201064498759
}

\begin{abstract}
Purpose. Although the hydrocyclone separator has many advantages, it still has some limitations which decrease its separation efficiency in many mineral processing applications because of fine particles which are miss separated to the coarse product in the underflow. Water injection in the conical part of the cyclone was recently implemented to solve this problem. The water injection mechanism and the way in which the injected water affects the separation are still not clear and need to be more investigated.
\end{abstract}

Methods. New design of water injection hydrocyclone was tried using a modified conical part with a water injection range consist of five equal distance injection openings open directly on the periphery of the cone part.

Findings. This study presents a mechanical mathematical model that simulates the water injection to give a clear indication of the injection mechanism impact on the classification process. It could also predict the dependence of the basic characteristics of the classification on the amount of the injected water and the influence of different operating and design parameters of the hydrocyclone.

Originality. The model accounts for the fluid flow, the particle motion, the turbulent particle diffusion, and particle settling. Particle interactions and fine particle entrainment by settling coarse particles are also included in the model. The model was found to predict well the injection effect and agrees with the experimental results.

Practical implications. The results showed also that the increase in water injection velocity leads to an increase in both the cut size and the minimal value of the separation curve. It was found also that the hydrocyclone length has an important effect on the injection process, and the separation sharpness is directly proportional to it at higher values of water injection velocity.

Keywords: hydrocyclone, water injection, mathematical model, separation efficiency

\section{Introduction}

Although the hydrocyclone separator has many advantages, but the conventional one (typical design) still have some limitations which decrease its separation efficiency in many industry applications. These limitations may be due to the following reasons: the cut size lies outside the desired region, the fine particles fractions are not adequately captured by the classification, and the sharpness of separation of the solid material is not high enough. Progress in hydro classification during the last $50^{\text {th }}$ years led to the development of a number of technical improvements in the design of hydrocyclone contributing to the advancement of the desired characteristics. One of the most effective methods of improving the characteristics of hydrocyclone is the water injection in the region of the high concentration solid phase (near the underflow opening). This technique has repeatedly reflected in the literature [1]-[5] and still currently on the way of further development.

The simplest theoretical point of view on the mechanism of injection impact on the classification performance can be concluded to the imagination of washout the particles from the wall, where the zone filled with concentrated solid material is exist. It is assumed that the velocity of the injecting water which carries the particles in the direction from the wall towards the kernel flow is higher, at least for particulate fines, than their own sedimentation rate to the wall. Accordingly, the fine particles will be mostly moved together with the mean flow to the overflow [6]-[8]. 
The aim of the present work is, based on (Dueck et al., 2009), to develop a simple mechanical-mathematical model which could give a clear indication of the impact injection mechanism for the classification process. It could also predict the dependence of the basic characteristics of the classification on the amount of the injected water and the influence of different operating and design parameters which characterize the hydrocyclone (hydrocyclone diameter, overflow and underflow openings diameters, feed pressure, properties of processed suspension) on the classification characteristics. The simulation results were examined and compared with the experimental results obtained from the experiments which carried out through the present work using $50 \mathrm{~mm}$ water injection hydrocyclone [9]-[12].

\section{The water injection hydrocyclone model}

\subsection{The formulation of the model}

The model, focuses on the following main factors which determine the classification process in a hydrocyclone: the movement of particles under the influence of the mass (centrifuge) forces to the wall, the diffusion of particles through turbulent diffusion caused by gradient of concentration of solid material (usually from the wall), and the flow of water injection. As can be shown in Figure 1, a classifier in form of a tube [13]-[15] of length and height $h$, where the suspension flows from the left to the right at a constant velocity will be considered. At the exit there are two discharges underflow (coarse) and overflow (fine). The particles in the suspension are subjected to the action of the centrifugal force along the y-axis and to the turbulent diffusion. Thus, the particles in the classifier move from left to right and settle in the vertical direction.

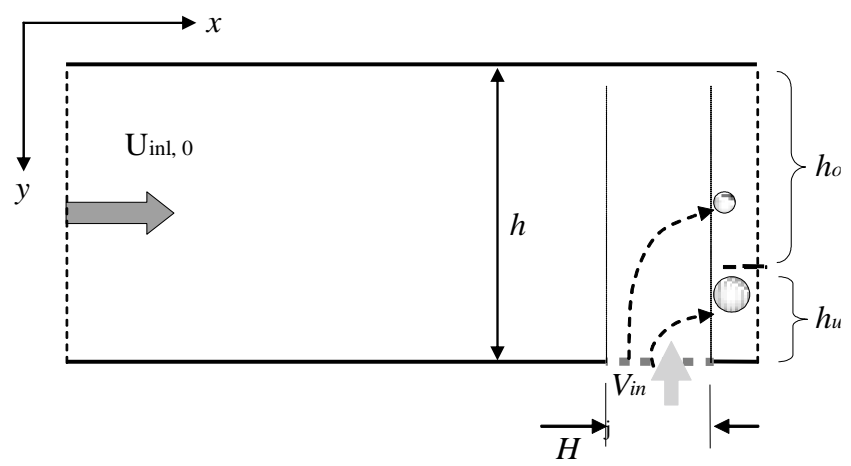

Figure 1. The simplified schematic of a classifier (hydrocyclone)

At the range of the length $H$ immediately before the expiration of suspension the injection is made transverse to the main flow of water in such a way as to remove (mostly smaller) particles from the wall. This injection should be sufficient to "transfer" fine particles in the discharge upper section. But the injection should be quite weak, so that larger particles still were withdrawn through the bottom hole. We will consider that $\frac{d_{j}^{2}}{v} / \frac{d_{j}}{\left|V_{i n}-V_{s, j}\right|}<<1$ (particles are non inertial).

The equation for determining the particle concentration of each fraction will be written in the form of the system of equation, which describes the evolution of the volume concentration of the $j$-th size fraction (particles with diameter $d_{j}$ ) in the apparatus: $\frac{\partial U_{i n l}(x) c_{j}}{\partial x}+\frac{\partial}{\partial y}+\left[\left(V_{s, j}+V_{i n}\right) c_{j}-D \frac{\partial c_{j}}{\partial y}\right]=0$.

The boundary conditions are:

$\left(V_{s, j}+V_{i n}\right) c_{j}-D \frac{\partial c_{j}}{\partial y}=0$ for $y=h$

$V_{s, j} c_{j}-D \frac{\partial c_{j}}{\partial y}=0$ if $y=0$.

The condition in the entry is:

$\left.c_{j}\right|_{x=0}=c_{j, 0} \cdot$

\subsection{The model of jet injection}

As a part of a simplified model an injection can be presented in the form of jet, flowed on a wall. In a simplified form the component of injection velocity along the jet will be described by a linear function of the coordinates across the main currents in the apparatus:

$V_{\text {in }}(y)=\left\{\begin{array}{l}0,0<x \leq L-H \\ \left(-\frac{y}{h}\right) V_{\text {in }, 0}, L-H<x \leq L\end{array}\right.$.

The component of the velocity along the axis of the device is restored, based on the volume conservation equation:

$\frac{U_{i n l}(x)}{U_{i n l, 0}}=\left\{\begin{array}{l}1,0<x \leq L-H \\ 1+\frac{V_{i n, 0}}{U_{i n l, 0}}\left(\frac{x-(L-H)}{h}\right), L-H<x \leq L\end{array}\right.$

\subsection{Modeling of particle sedimentation in a polydisperse suspension}

Experimental and theoretical results on settling of dense suspensions were developed by many investigators, whose studies were focused on the settling behavior of polydisperse suspensions. It has been observed that the settling velocity of the fine particles increases in the presence of coarser fractions. This phenomenon has been explained by different model considerations. Herewith, the results [16] on the settling of the dense suspensions are used.

In polydisperse suspensions, the most important effects which act on the settling particle are as follows: increasing the "effective" density and the viscosity of the fluid, counter flow of the displaced fluid caused by settling particles, and entrainment of fine particles in the boundary layer range of coarse settling particles.

The complete equation for the settling velocity of $j$-fraction particles is summarized as follows [17], [18]:

$V_{s, j}=\frac{V_{H, j}}{d_{j}^{2}}\left[\begin{array}{l}d_{j}^{2}+g\left(c_{V}\right) f_{E}\left(d_{j}\right)- \\ -c_{v} \sum_{i=1}^{n} d_{i}^{2}+g\left(c_{V}\right) f_{E}\left(d_{j}\right) \frac{c_{j}}{c_{V}} \Delta d_{j}\end{array}\right]$.

In Equation 6 the first term describes the hindered particle settling velocity due to the modification of the effective viscosity and density of the suspension where, the second term is responsible for an increasing of the settling velocity due to the entrainment of the fine particles by coarser ones and the third 
term considers a decreasing of settling velocity because of the counter flow of displaced liquid. From Equation 6 it can be concluded that in a polydisperse suspension, the settling velocity of a particle depends not only on the total solids concentration $c_{v}$ but also on the particle size distribution.

Here, $V_{H, j}=V_{S t, j}\left(1-c_{v}\right) \cdot\left(1-c_{v} / 0.6\right)^{1.5}$ is the function, which considered the hindering of the settling due to altering of viscosity and density; $g\left(c_{v}\right)=4.0 \cdot c_{v}^{2 / 3} \exp \left(-\left(c_{v} / 0.2\right)^{3}\right)-$ the correction function from experiments; $f_{E}\left(d_{j}\right)=\left(\sum_{i>j} \Delta m_{i} d_{i}^{6}\right)^{1 / 3}-$ the entraining function; $\Delta m_{i}=c_{i} / c_{v}-$ relative volume ratio of particles of $j$-th fraction; $c_{v}-$ the total volume concentration of solid phase; $\beta$-parameter, which characterizes the size of particle, which can entrain the finest particles; $V_{S t, j}=b\left(g d_{j}^{2} / 18 \mu_{L}\right) \cdot\left(\rho_{p}-\rho_{L}\right)-$ sedimentation rate after the Stokes rate; $b$-centrifugal Number (ratio of the centrifugal acceleration to the $g$ - gravitational one); $\mu_{L}-$ liquid viscosity; $\rho_{p}-$ solid density; $\rho_{L}$ - liquid density.

The condition of selecting $i$ for a given value of $j$ can be obtained on the basis of the inequality derived for the bidisperse suspension [19]: $d_{i} \geq \beta d_{j}$, where $\beta$ is a constant, whose theoretical value confirmed by experiments, is in the range of 10 to $15 . \Delta m_{i}$ is the ratio of the particles volume of the $i$-th size fraction to the total volume of solid particles, which is related to the solid concentration $c_{i}$, because the ratio $c_{i} / \sum c_{i}$ also denotes the portion of volume of the $i$-th fraction. It can be written $\Delta m_{i}=c_{i} / \sum c_{i}=q\left(d_{i}\right) \Delta d_{i}$. Using the known or calculated concentrations the density of particle size distribution can be calculated at every point of apparatus as $q\left(d_{i}\right)=c_{i} / \Delta d_{i} \sum c_{i}$.

\subsection{Definition of separation curve}

Considering the width of the upper top output holes will be $h_{0}$ (Fig. 1), then $-h_{u}=h-h_{0}$ the width of the underflow exhaust. The attitude $S$ is called split-parameter where:

$$
S=\frac{\int_{0}^{h_{0}} U_{i n l}(x, y) d y}{\int_{h_{0}}^{h} U_{i n l}(x, y) d y} .
$$

At no injection, $U_{i n l}(x)=U_{\text {inl, } 0}$ and $S_{0}=h_{0} / h_{u}$, and its value is usually about 10 . The flow of particles $j$-th factions through the upper and lower holes, respectively, defines the following functions:

$$
\begin{aligned}
& \int_{h_{0}}^{h} R_{u n, j}=\int_{h_{0}}^{h_{u}+h_{0}} U_{i n l}(L) c_{j}(L, y) d y ; \\
& R_{o v, j}=\int_{0}^{h_{0}} U_{i n l}(L) c_{j}(L, y) d y .
\end{aligned}
$$

These features characterize the degree of separation of particles of each faction. Large particles mostly pass through the underflow (lower discharge), and the small ones across the overflow (upper discharge). The separation function, showing the percentage of every particle fraction separated through the underflow (bottom) hole, in accordance with the model of separation [19] will be:

$$
T\left(d_{j}\right)=\frac{R_{u n, j}}{R_{u n, j}+R_{o v, j}} .
$$

The function of separation and classification process is characterized, mainly, by the following parameters:

a) the fine percentage separated in the underflow and defined by the separation function for the smallest fraction $T_{0}$;

b) the $d_{j}^{[50]}$ - the diameter of the separation of particles recorded at $50 \%$ in the underflow (so-called cut size);

c) the sharpness of the separation, which is determined by the ratio of particle sizes, corresponded to the values of the separation functions of 0.25 and 0.75 :

$$
Q u=\frac{d_{j}^{[25]}}{d_{j}^{[75]}} .
$$

\section{Experimental work}

\subsection{Test rig and procedure}

The test-rig used in the experimental work of this research consisted of a $50 \mathrm{~mm}$ water injection hydrocyclone positioned vertically above a feed tank (Fig. 2a). The water injection hydrocyclone which was used through this work is a conventional hydrocyclone with a modified conical part to have a water injection mechanism (Fig. 2b).

The water injection assembly consists of an outer solid ring and inner solid ring with 5 inlet openings at equal distances open directly on the periphery of the cone part. This assembly is connected with a control valve of water through which the water can be entered in the assembly and is injected through these openings [20], [21]. (a)

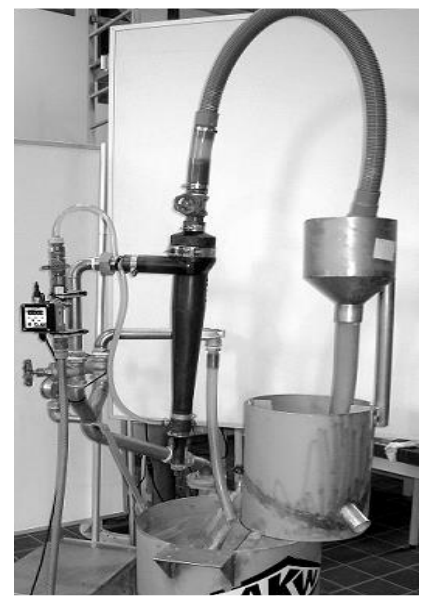

(b)

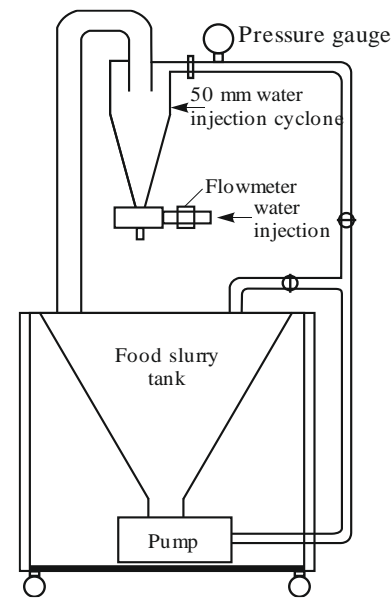

Figure 2. Water injection hydrocyclone test rig

Digital manometer was fixed near the water injection to indicate the water injection rate. The ring was designed to permit the water to be injected in a tangential direction with the same swirling motion of the flow inside the hydrocyclone. The water injection part was added near the apex of the cyclone without causing any extension of the total cyclone length. Due to the water injection process, the feed water reporting to the underflow will be displaced by injected water carrying the misreported fines into the overflow. To investigate the effect of water injection rate on the hydrodynamics of the separation, the samples were taken at different flow rates. From these samples, the feed flow rate, overflow flow rate, and underflow rate can be calculated at every test from which the split parameter can be estimated. 


\subsection{Choice of parameters for the calculation}

The dimensions of the used hydrocyclone were as follows: hydrocyclone diameter $D_{c}=50 \cdot 10^{-3} \mathrm{~m}$; hydrocyclone length $L=0.6 \mathrm{~m}$; inlet opening diameter $D_{f}=14.5 \cdot 10^{-3} \mathrm{~m}$; underflow diameter $-8 \cdot 10^{-3} \mathrm{~m}$, overflow diameter $D_{o}=16 \cdot 10^{-3} \mathrm{~m}$; area of the feed inlet $S_{f}=165 \cdot 10^{-6} \mathrm{~m}$. The calculations were done using the following parameters: constant of turbulent diffusion $D_{t}=10^{-3} \mathrm{~m}^{2} / \mathrm{s}$; split-parameter $S=9$; initial inlet velocity $1.2 \mathrm{~m} / \mathrm{s} ; L=0.6 \mathrm{~m} ; h=50 \mathrm{~mm}=5 \cdot 10^{-2} \mathrm{~m}$; diameter of injection opening $h_{\text {in }}=2.5 \cdot 10^{-2} \mathrm{~m}$ ( 5 openings). Initial total volumetric concentration of suspension is equal to 0.094 , the number of fractions has been chosen to be equals to 51 . Obviously, these data on the schematized apparatus are taken only as an approximation and serve only the purpose of the qualitative comparison of calculated and measured values.

\section{Results and discussion}

\subsection{Effect of water injection}

The used particle size distribution of feed, overflow, and underflow suspensions are shown in Figure 3 in the case of no water injection.

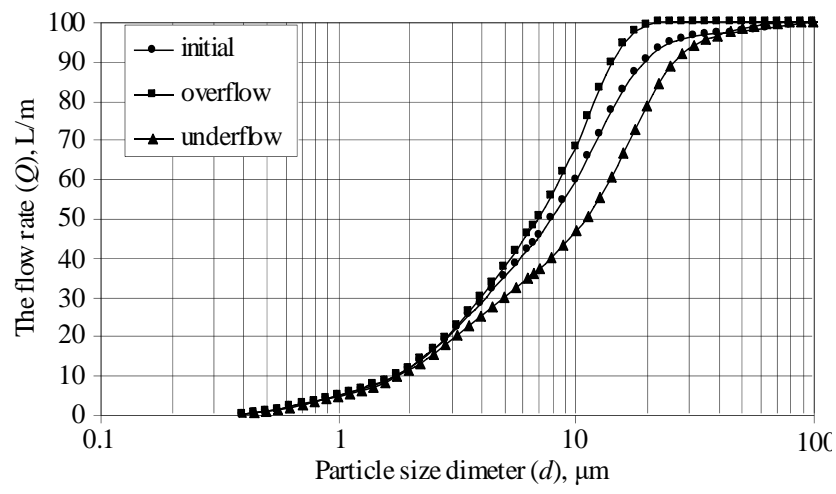

Figure 3. Particle size distribution of feed, overflow, underflow suspensions in the case of no water injection

These curves indicate the classification effect in apparatus in the normal operation (without water injection). The injection of water changes these distributions. Mostly this change has to occur only in the underflow (for the optimum washing effect). Figure $4 \mathrm{a}$ shows, that for the computed results only the underflow suspensions show the difference in the particle size distribution due to the injection, whereas the overflow does almost not influence by the injection. Such situation is desired in the practice.

It can also be shown that, although the difference in size distribution between the calculated and the measured data for underflow streams is rather greater as it for the material in overflow but there is also a clear qualitative coincidence. The comparison of the separation curves obtained from numerical calculations and experiments can be seen in Figure 5. It is indicated that the calculated separation curves are similar to the measured ones, but they show some of peculiarities. Firstly, by increasing the injection rate, the cut size increases numerically much stronger than experimentally. Further, in the theoretical model the "fish-hook" effect is less obvious than in the experiments. However, the change of the minimal value of separation curve $T_{0}$ in both cases (calculations and experimental) decreases approximately similar if the injection rate increases. (a)

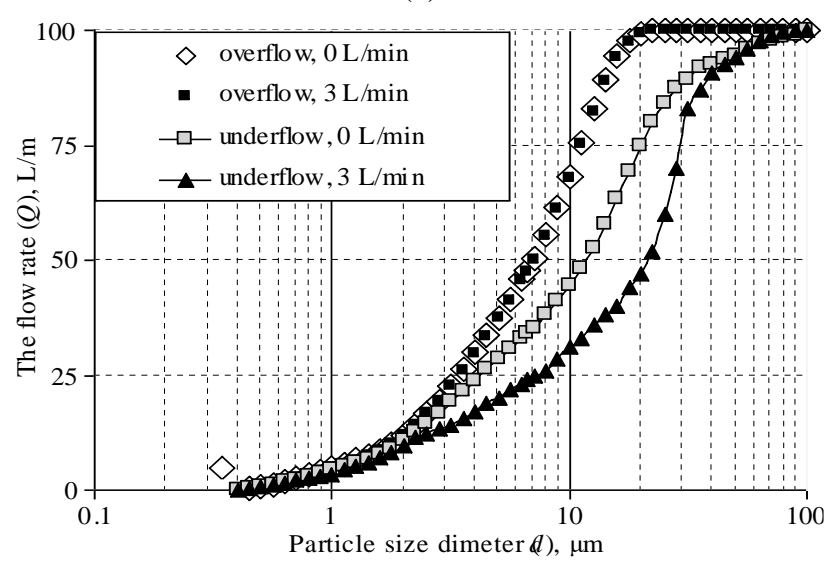

(b)

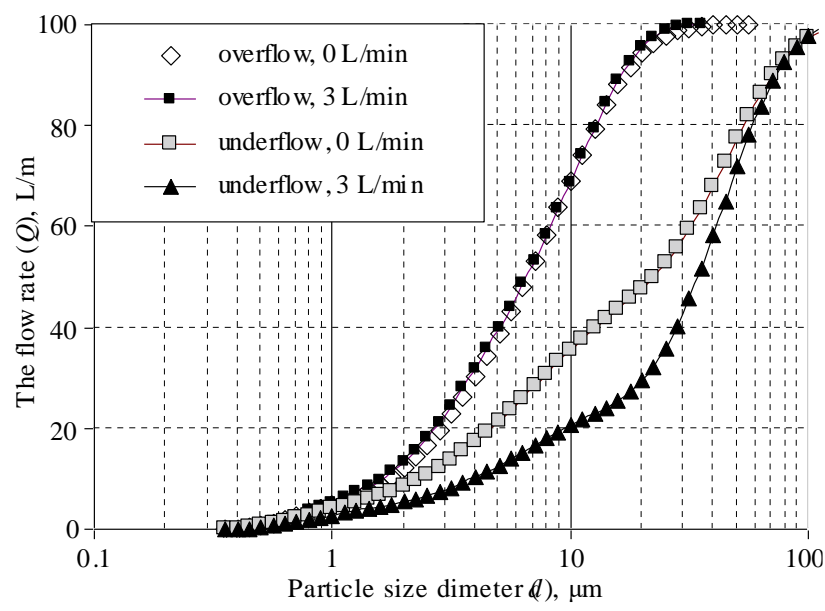

Figure 4. Comparison of the particle size distribution of overflow and underflow with water injection $\left(V_{\text {in }, 0}=3 \mathrm{~L} / \mathrm{min}\right)$ and without water injection: (a) calculation; (b) measurements

(a)

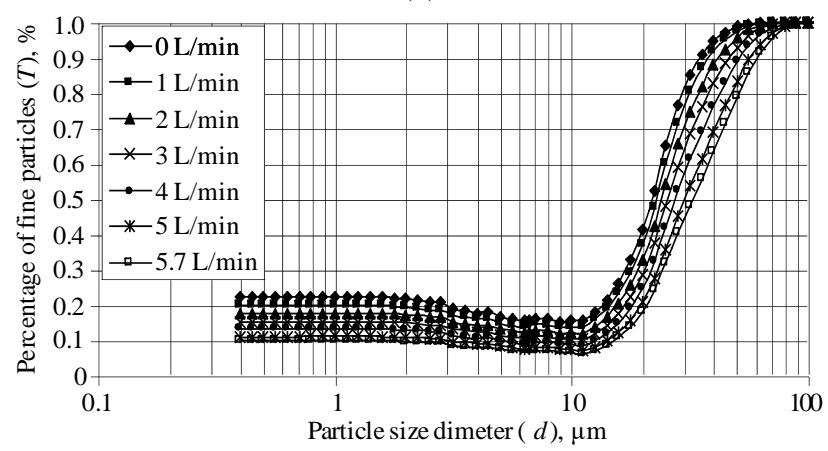

(b)

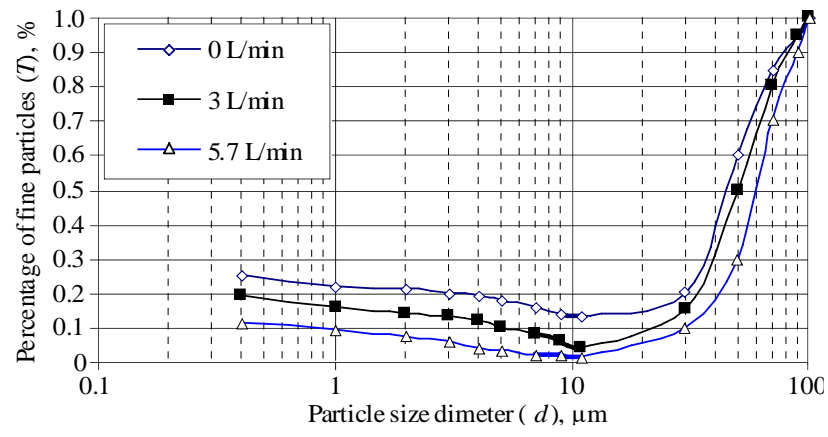

Figure 5. The separation curves at different injection velocities: (a) numerical simulation; (b) experiment 
It is also shown that the non-monotonous character of the separation curve becomes weaker if the injection becomes stronger (high injection rates). The dependences of $T_{0}$ and $d_{50}$ on the injection rate are shown in Figures 6 and 7.

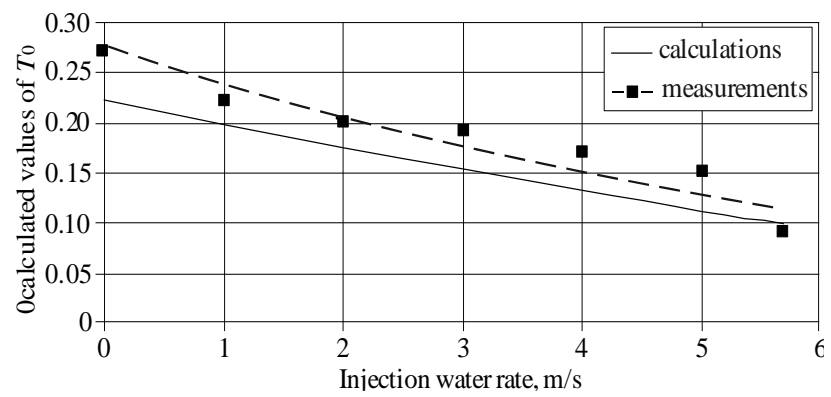

Figure 6. Comparison of the calculated values of $T_{0}$ with the measured ones as a function of the injected water rate

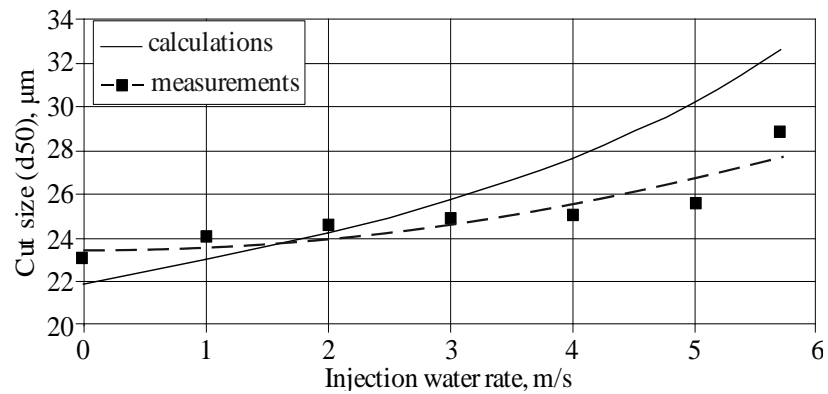

Figure 7. Comparison of the calculated values of cut sizes $d_{50}$ with the measured ones as a function of the injected water rate

The sharpness of the separation of the used disperse material through the apparatus with the considered characteristics decreases with the increase of injection rate in both calculations and experimental results as shown in Figure 8.

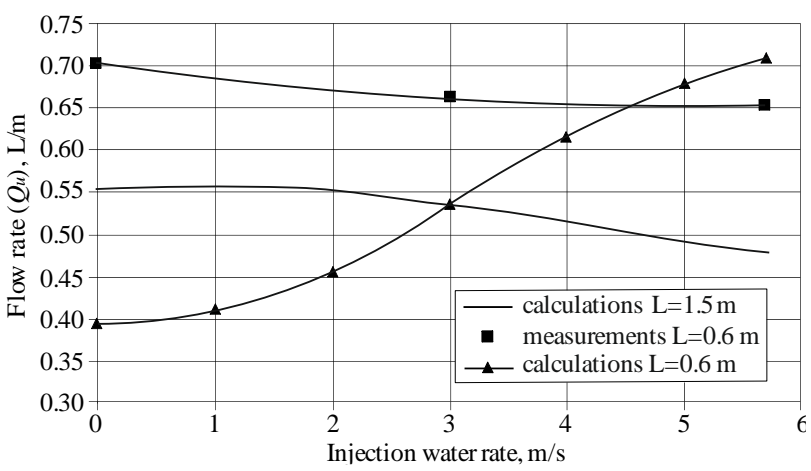

Figure 8. Comparison of the calculated values of the separation sharpness with the measured ones as a function of the injected water rate

It should be noted also that the above presented results differ qualitatively from the dependence described in the literature in which $Q_{u}$ increases by increasing the injection rate as it has been shown in Figure 8. The possible reasons of this will be explained afterward.

Figure 9 shows that the total solid concentration decreases in the underflow and increases in the overflow by increasing the injection rate. It can be seen that both the calculated and the experimental results have a good agreement with each other.

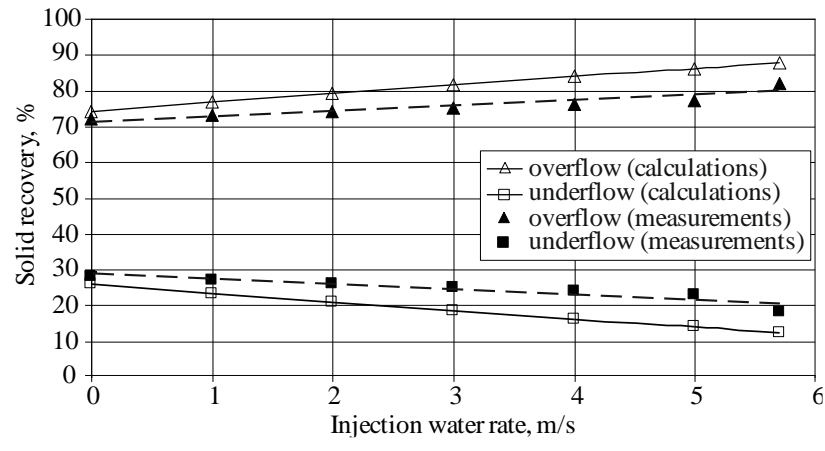

Figure 9. Comparison of the calculated values of the solid concentration in underflow and in overflow with the measured ones as a function of the injected water rate

\subsection{The analytic approximations}

The results shown in Figures 5 through 8 can be explained with the use of the approximate solutions of system (1-3) in the limited case assuming that the total solid concentration in suspension is very low and the injection part is wide enough $H \approx L$. Then the distribution of the particles concentration across the apparatus follows the equation:

$\left(V_{s, j}+V_{i n}\right) c_{j}-D \frac{d c_{j}}{d y}=0$

In frame of formulated model for injection jet the solution is:

$\ln \frac{c_{j}(y)}{c_{j}(0)}=\frac{V_{s, j}}{D} y-\frac{V_{i n, 0}}{D h} \frac{y^{2}}{2}$.

For the separation functions yields:

$T\left(d_{j}\right)=\frac{1}{1+S \exp \left[-\frac{h}{D}\left(V_{s}\left(d_{j}\right)-0.5 V_{i n, 0}\right)\right]}$.

For $d_{j} \rightarrow 0$ from (12) follows:

$T(0)=\frac{1}{1+S \exp \left[\frac{h}{2 D} V_{i n, 0}\right]}$.

Obviously, that $T(0)$ decreases if the injection rate increases. Considering $d^{[50]}(0)$ as the cut size in the absence of injection, the ratio is valid:

$\frac{d^{[50]}}{d^{[50]}(0)}=\sqrt{1+\frac{h}{2 D \ln S} V_{i n, 0}}$.

Similarly, determining $d_{j}^{[25]}$ and $d_{j}{ }^{[75]}$ from Equation 14, the sharpness of the separation can be calculated as follows:

$Q u=Q u_{0} \sqrt{\frac{1+\frac{h V_{i n, 0}}{2 D} \frac{1}{\ln \left(\frac{S}{3}\right)}}{1+\frac{h V_{i n, 0}}{2 D} \frac{1}{\ln (3 S)}}}$,

where: 
$Q u_{0}=\frac{\ln \left(\frac{S}{3}\right)}{\ln (3 S)}-$ the sharpness in absence of injection i.e., the separation sharpness increases with increasing of the injection speed. With increasing $V_{i n, 0}$ the sharpness tends to 1 .

\subsection{Solid concentration curves}

The literature review has showed that many attempts were tried to regulate the characteristics of hydrocyclone classification by using water injection near the underflow opening [22]. These studies are still limited and insufficient to describe individual, concrete structures injectors and single measurements, indicating a significant impact on injection separation curve especially at different quantities of water injection and the systematic measurements are random. So, in provides $d^{[50]} \infty W_{i n, 0} 0.6$ for the dependence of cut sizes. The ratio of the solid material discharging through the overflow increases and decreases through the underflow. According to Equation 16, at high-speed injection, the cut size should be in proportion to the square root of the speed of injected water. In [23] the effect of injection on the performance of $100 \mathrm{~mm}$ hydrocyclone has been studied. An empirical formula reflecting the facts of increase $d^{[50]}$ or decrease $T_{0}$ with the increase in speed injection is proposed. The experimental data on the cut size can be described as dependence $d^{[50]} \infty W_{i n, 0}{ }^{1.1}$, which is more sensitive to that obtained by approximation calculations on a theoretical model $d^{[50]} \infty W_{i n, 0}{ }^{0.66}$.

Experimental dependence of the minimum value of the separation curve $\left(T_{0}\right)$ of speed injection [5] can be roughly describe by the dependence $T_{0} \infty W_{i n, 0}{ }^{-0.82}$, while the approximation (13) predicts exponential drop of $T_{0}$ by increasing $W_{i n}$. It should be noted also that the theoretical dependence Equation 15 reflected true the increase of the separation sharpness with an increase of injection speed, measured in [23]. Thus, the proposed model reflects a known fact which agrees with the literature concerning the changes happens in the separation curves of classifiers like hydrocyclone in the case of using water injection through the apparatus. Concerning to the present work experiments, they emphasize the strong differences between analytical assessments and the experimental data and the computer calculations as shown in Figures 5 through 8. Probably, the reason is not full establishing of particles concentrations of different fractions.

Figure 10 shows the evolution of concentration curves along the axis of apparatus. Obviously, at a distance of $0.6 \mathrm{~m}$ the concentrations significance is far from established.

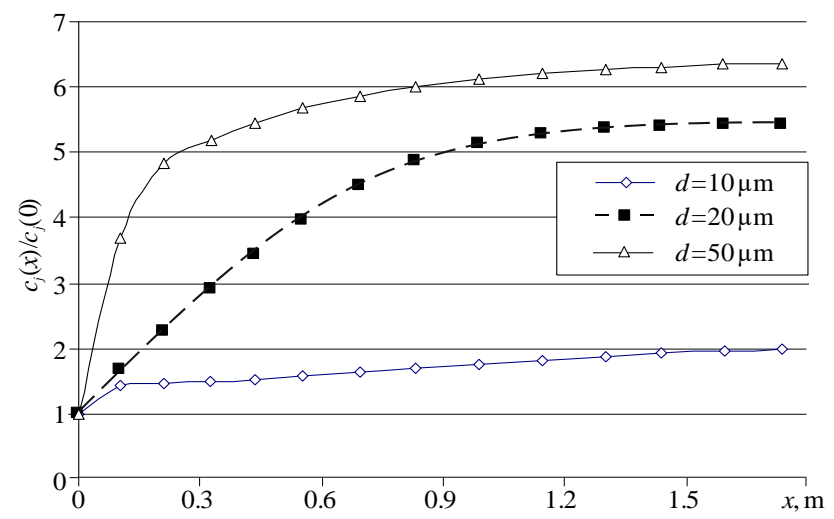

Figure 10. Evolution of the solid concentration along the apparatus for the particles size fractions $(d=10 \mu m$; $d=20 \mu \mathrm{m} ; d=50 \mu \mathrm{m})$ at the case of no water injection
Figure 11 shows the calculated values of $d_{50}$ and $T(0)$ in the case of $L=1.5 \mathrm{~m}$. It is obvious that in this case the impact of injection velocity on $\mathrm{d}_{50}$ is much stronger than for a shorter apparatus. This dependence is more close to the theoretical Dependencies 15 and 16.

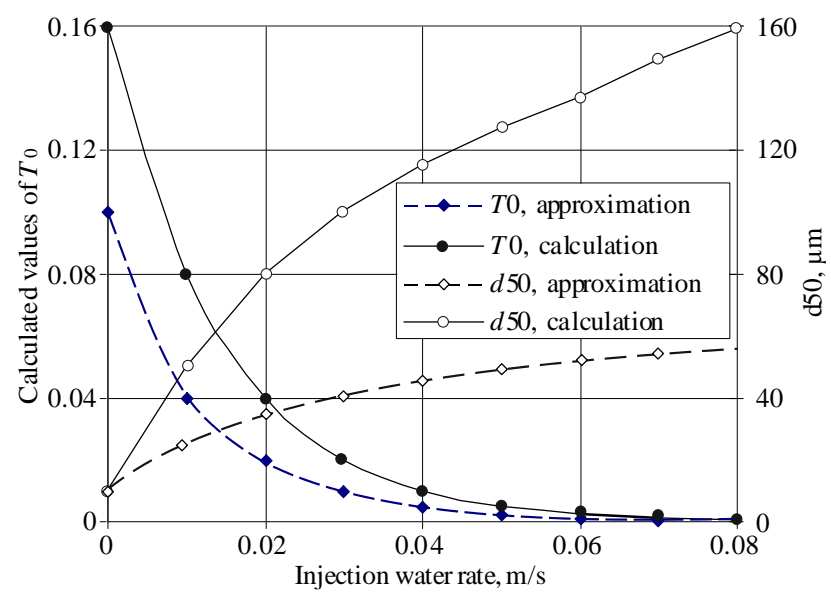

Figure 11. Dependence of $T(0)$ and $d_{50}$ on the injection velocity (injection throughput) in the case of $L=1.5 \mathrm{~m}$. Comparing with the analytical evaluation

\section{Conclusions}

The conclusions of the present work can be summarized as follows:

1. Increasing the injected water speed leads to an increase in both cut size $d_{50}$, and the minimum value of the separation function $T(0)$.

2. Injection promotes the extinction of non-monotonic for the separation curve of dense suspensions.

3. The apparatus length has an important effect on the injection process i.e., the injection effect is different for a long and a short hydrocyclone.

4. The separation sharpness for a short apparatus decreeses and for a long apparatus increases if the velocity of injected water increases.

\section{Acknowledgements}

We would like to thank DAAD for its support and Prof. Minkov for providing documents and data required to develop the analytical model.

\section{References}

[1] Bradley, D. (1965). The hydrocyclone. London, United Kingdom: Pergamon Press.

[2] Lim, E.W.C., Chen, Y.-R., Wang, C.-H., \& Wu, R.-M. (2010). Experimental and computational studies of multiphase hydrodynamics in a hydrocyclone separator system. Chemical Engineering Science, 65(24), 6415-6424. https://doi.org/10.1016/j.ces.2010.09.029

[3] Kelsall, D.F., \& Holmes, J.A. (1990). Improvement in classification efficiency in hydrauliccyclones by water injection. Proceedings of the $5^{\text {th }}$ Mineral Processing Congress, 159-170.

[4] Ghodrat, M., Kuang, S.B., Yu, A.B., Vince, A., Barnett, G.D., \& Barnett, P.J. (2013). Computational study of the multiphase flow and performance of hydrocyclones: Effects of cyclone size and spigot diameter. Industrial \& Engineering Chemistry Research, 52(45), 1601916031. https://doi.org/10.1021/ie402267b

[5] Hararah, M.A., Endres, E., Dueck, J., Minkov, L., \& Neesse, T. (2009). Flow conditions in the air core of the hydrocyclone. Minerals Engineering, 23(4), 295-300. https://doi.org/10.1016/j.mineng.2009.12.013

[6] Udaya Bhaskar, K., Govindarajan, B., Barnawal, J.P., Rao, K.K., \& Rao, T.C. (2004). Modelling studies on a $100 \mathrm{~mm}$ water-injection cy- 
clone. Physical Separation in Science and Engineering, 13(3-4), 89-99. https://doi.org/10.1080/14786470412331286580

[7] Udaya Bhaskar, K., Govindarajan, B., Barnawal, J.P., Rao, K.K., Gupta, B.K., \& Rao, T.C. (2005). Classification studies of lead-zinc ore fines using water-injection cyclone. International Journal of Mineral Processing, (77), 80-94. https://doi.org/10.1016/j.minpro.2005.02.007

[8] Farghaly, M.G. (2009). Controlled wash water injection to the hydrocyclone underflow. PhD Thesis. Nuremberg, Germany: University Erlangen.

[9] Dueck, J.G., Minkov, L.L., \& Pikushchak, E.V. (2006). On separation curves of a throughput classification apparatus of finite length. Journal of Engineering Physics and Thermophysics, 79(4), 171-178 https://doi.org/10.1007/s10891-006-0141-y

[10] Zhang, Y., Qian, P., Liu, Y., \& Wang, H. (2011). Experimental study of hydrocyclone flow field with different feed concentration. Industrial and Engineering Chemistry Research, 50(13), 8176-8184. https://doi.org/10.1021/ie100210c

[11] Dubey, R.K., Climent, E., Banerjee, C., \& Majumder, A.K. (2016). Performance monitoring of a hydrocyclone based on underflow discharge angle. International Journal of Mineral Processing, (154), 41-52. https://doi.org/10.1016/j.minpro.2016.07.002

[12] Dueck, J.G., Min'kov, L.L., \& Pikushchak, E.V. (2007). Modeling of the "fish-hook" effect in a classifier. Journal of Engineering Physics and Thermophysics, 80(1), 64-73. https://doi.org/10.1007/s10891-0070009-9

[13] Neesse, Th., Schubert, H., \& Graichen, K. (1991). Practical and theoretical aspects of dense-flow classification. Aufberei-Tungstechnik, 32(9), 459-472. https://doi.org/10.1016/0379-6787(91)90078-4

[14] Dueck, J., Krokhina, A., Minkov, L.L., \& Neesse, T. (2009). Hydrodynamics of a cyclone with wash water injection. Proceedings of the $7^{\text {th }}$ World Conference on Experimental Heat Transfer, Fluid Mechanics and Thermodynamics.
[15] Dueck, J.G., Pikushchak, E.V., \& Minkov, L.L. (2009). Modelling of change of the classifiers separation characteristics by water injection into the apparatus. Thermophysics and Aeromechanics, 16(2), 247-258. https://doi.org/10.1134/S0869864309020097

[16] Ghodrat, M., Kuang, S.B., Yu, A.B., \& Vince, A. (2014). Numerical analysis of hydrocyclone with different vortex finder configurations. Minerals Engineering, (63), 125-138. https://doi.org/10.1016/j.mineng.2014.02.003

[17] Kuang, S.B., Chu, K.W., Yu, A.B., \& Vince, A. (2012). Numerical study of liquid-gas-solid flow in classifying hydrocyclones: Effect of feed solids concentration. Minerals Engineering, 31(0), 17-31. https://doi.org/10.1016/j.mineng.2012.01.003

[18] Narasimha, M., Brennan, M.S., \& Holtham, P.N. (2012). CFD modeling of hydrocyclones: Prediction of particle size segregation. Minerals Engineering, 39(0), 173-183. https://doi.org/10.1016/j.mineng.2012.05.010

[19] Minkov, L., \& Dueck, J. (2005). Collective effects by settling of polydisperse dense suspension. Eurasian Physical-Technical Journal, 2(1(3)), 47-63.

[20] Patil, D.D., \& Rao, T.C. (1999). Technical note, classification evaluation of water injected hydrocyclone. Mineral Engineering, 12(12), 1527-1532. https://doi.org/10.1016/S0892-6875(99)00139-9

[21] Udaya Bhaskar, K., Govindarajan, B., Barnawal, J.P., Rao, K.K., \& Rao, T.C. (2004). Modelling studies on a $100 \mathrm{~mm}$ water-injection cyclone. Physical Separation in Science and Engineering, 13(3-4), 89-99. https://doi.org/10.1080/14786470412331286580

[22] Udaya Bhaskar, K., Govindarajan, B., Barnawal, J.P., Rao, K.K., Gupta, B.K., \& Rao, T.C. (2005). Classification studies of lead-zinc ore fines using water-injection cyclone. International Journal of Mineral Processing, (77), 80-94. https://doi.org/10.1016/j.minpro.2005.02.007

[23] Neese, T., \& Dueck, J. (2007). Air core formation in the hydrocyclone. Minerals Engineering, 20(4), 349-354. https://doi.org/10.1016/j.mineng.2007.01.007

\section{Оптимізація сепараційних характеристик гідроциклону з нагнітанням води за допомогою математичного моделювання}

\section{Л. Мінков, І. Дюк, М.М.А. Хассан, М.А.М. Алі, М.Г. Фергалі}

Мета. Покращення сепараційних характеристик гідроциклону шляхом нагнітання води за допомогою математичного моделювання. Механізм нагнітання і те, як саме вода, що закачується, впливає на розділення, все ще не є зрозумілими і вимагають подальшого наукового вивчення.

Методика. Була випробувана нова конструкція гідроциклону із закачуванням води з використанням модифікованої конічної частини 3 діапазоном вприску води, що складається з п’яти отворів для вприску на рівній відстані, відкритих безпосередньо по периферії конічної частини. Математична модель фокусувалася на таких основних факторах, що визначають процес класифікації в гідроциклоні: рух частинок під дією масових (центрифужних) сил до стінки, дифузія частинок за допомогою турбулентної дифузії, спричиненої градієнтом концентрації, та потік закачування води.

Результати. Встановлено, що збільшення швидкості води, що нагнітається, призводить до збільшення як розміру фракції $d 50$, так і мінімального значення функції розділення $T(0)$, а ін'єкція сприяє гасінню немонотонної для кривої розділення щільних суспензій. Встановлено, що довжина пристрою має важливий вплив на процес впорскування, тобто ефект впорскування різний для довгого і короткого гідроциклону. Визначено, що різкість розділення для короткого апарату зменшується, а для довгого апарату збільшується, якщо швидкість води, що закачується, збільшується.

Наукова новизна. Математична модель враховує потік рідини, рух частинок, їх турбулентну дифузію та осадження. У модель також включені взаємодії частинок та віднесення дрібних частинок за рахунок осадження великих. Було виявлено, що модель гарно передбачає вплив нагнітання і в цілому добре узгоджується з експериментальними результатами.

Практична значимість. Результати дослідження корисні для проектування ефективних сепараційних характеристик гідроциклонів при збагаченні різних видів корисних копалин.

Ключові слова: гідрочиклон, нагнітання води, математична модель, ефективність розділення, крупність часток

\section{Оптимизация сепарационных характеристик гидроциклона с нагнетанием воды при помощи математического моделирования}

\section{Л. Минков, И. Дюк, М.М.А. Хассан, М.А.М. Али, М.Г. Фергали}

Цель. Улучшение сепарационных характеристик гидроциклона путем нагнетания воды при помощи математического моделирования. Механизм нагнетания и то, как именно закачиваемая вода влияет на разделение, все еще не ясны и требуют дальнейшего научного изучения.

Методика. Была опробована новая конструкция гидроциклона с закачкой воды с использованием модифицированной конической части с диапазоном впрыска воды, состоящим из пяти отверстий для впрыска на равном расстоянии, открытых непосредственно по периферии конической части. Математическая модель фокусировалась на следующих основных факторах, определяющих процесс классификации в гидроциклоне: движение частиц под действием массовых (центрифужных) сил к стенке, диффузия частиц посредством турбулентной диффузии, вызванной градиентом концентрации, и поток закачки воды.

Результаты. Установлено, что увеличение скорости нагнетаемой воды приводит к увеличению как размера фракции $d_{50}$, так и минимального значения функции разделения $T(0)$, а инъекция способствует гашению немонотонной для кривой разделения плотных суспензий. Установлено, что длина устройства имеет важное влияние на процесс впрыска, то есть эффект впрыска различен для длинного и короткого гидроциклона. Определено, что резкость разделения для короткого аппарата уменьшается, а для длинного аппарата увеличивается, если скорость закачиваемой воды увеличивается. 
Научная новизна. Математическая модель учитывает поток жидкости, движение частиц, их турбулентную диффузию и осаждение. В модель также включены взаимодействия частиц и унос мелких частиц за счет осаждения крупных. Было обнаружено, что модель хорошо предсказывает влияние нагнетания и в целом хорошо согласуется с экспериментальными результатами.

Практическая значимость. Результаты исследования являются полезными для проектирования эффективных сепарационных характеристик гидроциклонов при обогащении различных видов полезных ископаемых.

Ключевые слова: гидрочиклон, нагнетание воды, математическая модель, эффективность разделения, крупность частии 